\title{
RESPONSE OF CHINA ASTER (CALLISTEPHUS CHINENSIS L.) GENOTYPES TOWARDS FOLIAR APPLICATION OF GA3
}

\author{
Sudipta Biswas \\ PG Student \\ Department of Seed Science and Technology \\ Bidhan Chandra Krishi Viswavidyalaya \\ Mohanpur - 741252, Nadia, West Bengal, India \\ E-mail: sudiptabiswas.nxb96@gmail.com \\ Dr. Sanjoy Kumar Bordolui (Corresponding Author) \\ Assistant Professor \\ Department of Seed Science and Technology \\ Bidhan Chandra Krishi Viswavidyalaya \\ Mohanpur - 741252, Nadia, West Bengal, India \\ E-mail: sanjoy_bordolui@rediffmail.com \\ Dr. Raghunath Sadhukhan \\ Professor \\ Department of Genetics and Plant Breeding \\ Bidhan Chandra Krishi Viswavidyalaya \\ Mohanpur - 741252, Nadia, West Bengal, India \\ E-mail: drsadhukhan@gmail.com
}

Received: August 08, 2021 Accepted: August 29, 2021 Online Published: September 07, 2021

DOI: 10.46545/aijas.v5i1.197

URL: https://doi.org/10.46545/aijas.v5i1.197

\begin{abstract}
China Aster is one of the most popular flower that are used in ornamental garden. The demand for cut flowers of China aster is increasing day by day, but it has not been possible to supply the adequate amount of flowers especially during the festival season. The area under flower production is increasing year after year but farmers are not getting quality seeds in adequate quantity as very few farmers are taking up seed production because flower seeds loose their viability earlier than crop seeds. So, production of adequate quantity of quality seeds is essential to meet the demand. The present investigation was undertaken in Horticulture Research Station, Mondouri, B.C.K.V., Mohanpur, Nadia, West Bengal during Rabi season of 2018-19 and 201920. Over two consecutive years, six genotypes were evaluated the potentiality of for its growth and flowering, as well as to estimate the influence of $G_{3}$ through foliar application at preflowering stage on its seed production. In field three treatments were considered viz. $T_{1}$ (control i.e.no application of $\left.G A_{3}\right), T_{2}\left(G A_{3} @ 50 p p m\right), T_{3}\left(G A_{3} @ 100 p p m\right)$. According to the size of
\end{abstract}


flowers, highest was recorded in Local Mix $\left(G_{6}\right)$. So, it could be considered as the best performer genotype considering flower diameter. Seed yield plant ${ }^{-1}$ was recorded highest in Local White $\left(G_{5}\right)$, it could be considered as the best performer genotype considering its higher number of flowers plant ${ }^{-1}$ and number of seeds flower ${ }^{-1}$. GA3 $(100 \mathrm{ppm})$ could be utilized in a better way for greater enhancement in all those important parameters as overall influence of $G A_{3}$ has been found to improve seed yield plant $t^{-1}$ and all the important attributes. Concomitant consideration of seed yield and its important attributes may indicate to recommend foliar application of 100 ppm $\mathrm{GA}_{3}$ for enhancement in seed yield in all the genotypes. Similar to the seed yield and its attributes, plant growth and development have been noticed to be positively influenced by $\mathrm{GA}_{3}$ concentrations with a higher side after $100 \mathrm{ppm}$, may lead to recommend foliar application of 100 ppm $\mathrm{GA}_{3}$ for commercial cultivation of this crop irrespective of the genotypes.

Keywords: China Aster, $\mathrm{GA}_{3}$, Seed Yield.

\section{INTRODUCTION}

Indian culture is a pleasing mingling of various subcultures. The culture shows a close connection with flowers from ancient era. However, the social and economic aspects of flower growing were recognized much later. The offering and exchange of flowers on all social occasions apart from use of flowers in worshipping and use of flowers in home decoration and hair adornment of women have made more opportunity for commercial cultivation of flowers. Among the various types of flowers, asters are one of the most beautiful and diverse flowers. The name of Aster comes from Greek word 'aster', which means star. According to Greek mythology, the goddess Asterea looked at the sky to watch the stars but she couldn't see any stars. This incident made her sad and she started weeping, where her tears fell on the ground, asters began to grow there. In Victorian England, floriography i.e. coded communication through the exchange of flowers, was all the rage and asters, with their wide range of colors act as the perfect medium. Purple asters represented wisdom and royalty, and were most popular aster. White aster stood for purity, perfection, and innocence. Red asters stood for devotion whereas pink asters stood for love. These days floriography is not in fashion yet, but asters still have an active symbolic life. China Aster is a monotypic genus of flowering plants in the family Asteraceae which contains the single species. Cassini described China aster as Callistephus hortensis but Linnaeus named it as Aster chinensis. Then, Nees changed its name to Callistephus chinensis. The genus Callistephus is evolved from Greek word 'Kalistos' meaning 'most beautiful' and 'Stephos' which means 'a crown' referring to the flower head. Plants of china aster are erect, alternate bearing. It has broadly ovate or triangular ovate, irregularly toothed leaves. Flowers are solitary, contains two types of florets: ray florets and disc florets. The discs are ray florets are long and short. They have daisy like or star like flower heads with a yellow center. The most suitable character for the classification of China aster is by the shape of ray florets (Janakiram \& Rao, 2002). The wide spectrum of colour ranges available in China aster are pink, bluish violet, purple and white. Their attractive colour and long shelf life have made them a popular cut flower. Flower quality is primarily a varietal trait. It is influenced by climatic conditions of growing period. Optimum temperature and requisite photoperiod helps in obtaining better blooms of good size and high quality (Nagaraju et al., 2004).The advantages of growing aster are short duration, suitable as intercrop in coconut and it has good seed setting. It is normally winter season flowering annual which is adapted to wide range of agroclimatic regions. The flower colour is well developed in the temperature range of $20-30^{\circ} \mathrm{C}$ during day and $15-17^{\circ} \mathrm{C}$ 
during night with relative humidity of 50-60\% and 500-700mm rainfall. Flowers of china asters are used for various purposes like flower decoration, preparation of bouquets, garlands, landscape gardening for aesthetic purpose. It is commercially cultivated in various countries like India, France, Germany, Netherlands, U.K., Siberia, Russia, Japan, North America, Switzerland and England (Raghava, 1984). In India, China aster is largely grown on commercial scale in southern states mainly in Karnataka, Tamil Nadu, Andhra Pradesh, Maharashtra and also some eastern state like West Bengal. In Karnataka, the cultivated area is over an area of 775 lakh ha with an annual production of 6206 tonnes of flowers (Anonymous, 2000). Increased flower production, quality of flowers and perfection in the form of plants are important objectives to be followed in commercial flower production. So, it is essential to meet the demand of adequate quantity of quality seeds for flower as well as seed production. Application of $\mathrm{GA}_{3}$ is an effective plant growth hormone which stimulates the cells elongation. $\mathrm{GA}_{3}$ is a lead to produce high seed production. It has ability to regulate plant height, enhance branches, increase productive (Gavino et al., 2008; Yuan et al., 2003). With the above view, present investigation has been carried out to evaluate China aster flower crop by applying $\mathrm{GA}_{3}$ treatment and record its various seed quality parameters during 2018-2019 and 2019-2020 at Horticulture Research Station, Mondouri, Bidhan Chandra Krishi Viswavidyalaya, Mohanpur, Nadia, West Bengal, India with the main objective of assessment of the effect of $\mathrm{GA}_{3}$ on growth, development flowering and seed production of different genotypes of China Aster.

\section{MATERIALS AND METHODS}

The field experiment was conducted in new alluvial zone at Horticulture Research station, Mondouri, Bidhan Chandra Krishi Viswavidyalaya, Mohanpur, Nadia, West Bengal, India during rabi season of 2018-19 and 2019-20. Soil pH of experimental site was 6.6-6.7, containing organic carbon $0.74 \%$, sandy loam in texture, total available Nitrogen $0.07 \%$, Phosphorus 28.50 $\mathrm{kg} \mathrm{ha}^{-1}$ and potassium $78 \mathrm{~kg} \mathrm{ha}^{-1}$. Seeds of six China aster genotypes viz. Arka Kamini $\left(\mathrm{G}_{1}\right)$, Arka Archana $\left(\mathrm{G}_{2}\right)$, Arka Adya $\left(\mathrm{G}_{3}\right)$, Local pink $\left(\mathrm{G}_{4}\right)$, Local White $\left(\mathrm{G}_{5}\right)$ and Local Mix $\left(\mathrm{G}_{6}\right)$ were sown in the experimental plots. Standard agronomic practices and intercultural operations were followed for raising seedlings in individual plots. Forty days old healthy and uniformly grown seedlings were used for transplanting with a spacing of $40 \mathrm{~cm} \mathrm{x} 40 \mathrm{~cm}$ with three replications following Randomised Block Design. A spacing of $45 \mathrm{~cm}$ between two replications and $45 \mathrm{~cm}$ between two plots was given to design of water system channels and bunds, individually. The whole exploratory land was separated into plots estimating $2.5 \mathrm{~m} \times 2.5 \mathrm{~m}$. with 54 plots altogether. Farm yard manure was applied @ $2 \mathrm{~kg} \mathrm{plot}^{-1}$. Fertilizer dose of 10:26:26 (N:P: K mixed fertilizer) @ 150g plot ${ }^{-1}$ was applied as basal portion and another $50 \mathrm{~g} \mathrm{plot}^{-1}$ at 20 days after transplanting. Foliar application of both the doses of Gibberellic acid (i.e. 50 ppm and $100 \mathrm{ppm}$ ) was made on plants at three weeks after transplanting and the non-sprayed plants were treated as control. Five plants were randomly tagged at the early crop growth stage and observations on different traits were recorded by a specific method, like plant height $(\mathrm{cm})$, days to bud initiation, days $50 \%$ flowering, flower diameter $(\mathrm{cm})$, head diameter $(\mathrm{cm})$, number of flower plant ${ }^{-1}$, number of seed flower ${ }^{-1}$, test weight $(\mathrm{g})$ and seed yield plant $^{-1}(\mathrm{~g})$.

\section{RESULTS AND DISCUSSION}

Different agronomic characters excepting test weight for which it was made during 2018-19 and 2019-20 along with the quality parameters (physiological) of the produced seeds by considerations of effect of $\mathrm{GA}_{3}$ as foliar application was made over two consecutive years. 
Significant variation among the performance of the genotypes, influence of doses of $\mathrm{GA}_{3}$ as well as its interaction effects observed for all agronomic characters. Gibberellic acid (GA) is a tetracyclic di-terpenoid compound. It is a plant hormone stimulating plant growth and development. It influences seed germination, trigger transitions from meristem to shoot growth, vegetative to flowering and seed development along with an interaction of different environmental factors viz., water, light and temperature. $\mathrm{GA}_{3}$ is sometime act as paracrine signals; it is still a mystery to understand the $\mathrm{GA}_{3}$ biosynthesis and its movement. It has not yet established the significant site of bioactive $\mathrm{GA}_{3}$ in plants or which tissues earmarked by bioactive $\mathrm{GA}_{3}$ to commence their action.

\section{Plant Height (cm)}

Significantly tallest plants were observed for $\mathrm{G}_{4}$ (Local pink) followed by $\mathrm{G}_{6}$ (Local Mix), when average was made over the treatments, while most dwarf plants were recognized for $\mathrm{G}_{5}$ (Local White) $(50.277 \mathrm{~cm})$ preceded by $\mathrm{G}_{1}$ (Arka Kamini) and $\mathrm{G}_{2}$ (Arka Archana), significant difference could be noticed among genotypes during 2018-19 (Table 1). Average influence of $100 \mathrm{ppm}$ $\mathrm{GA}_{3}$ was significantly superior to that of $50 \mathrm{ppm} \mathrm{GA} 3$ over control for exhibition of plant height at $50 \%$ flowering stage. While considering the interaction between genotypes and treatments, significantly maximum plant height was recorded for $\mathrm{G}_{4}$ after application of $100 \mathrm{ppm} \mathrm{GA}_{3}$ followed by same genotype after application with $50 \mathrm{ppm}$ of $\mathrm{GA}_{3}$. Similar to the average influence of $\mathrm{GA}_{3}$ doses, high $\mathrm{GA}_{3}$ dose exerted greater influence than that of lower dose for almost all the genotypes for which significant difference between influences of both the doses of $\mathrm{GA}_{3}$ was recognized.

Average plant height at $50 \%$ flowering of $\mathrm{G}_{4}$ (i.e., Local pink) was also found to be maximum $(69.452 \mathrm{~cm})$ followed by that of $\mathrm{G}_{6}$ (i.e., Local Mix) when average was made over the treatments during 2018-19 as was observed in second year; same like first year, $\mathrm{G}_{5}$ (Local White) produced dwarf plants of average $50.154 \mathrm{~cm}$ height preceded by those of $\mathrm{G}_{1}$, significant difference could be noticed in 2018-19. Significantly enhanced average plant height over control (without application of $\mathrm{GA}_{3}$ ) could also be recorded after application of $\mathrm{GA}_{3}$ and plant height increased with the increased concentration of $\mathrm{GA}_{3}$ (Table 1). The trend in enhancement in plant height of individual genotypes also followed the similar pattern as was recorded for average influence of $\mathrm{GA}_{3}$ concentration and significant difference between influence of 50 and $100 \mathrm{ppm}$ $\mathrm{GA}_{3}$ could be noticed. Plant height was recorded to be as maximum as $75.963 \mathrm{~cm}$ for $\mathrm{G}_{4}$ after application of $100 \mathrm{ppm} \mathrm{GA}_{3}$ followed by that of same genotype after application of $50 \mathrm{ppm}$ of $\mathrm{GA}_{3}$. Similar type of result in plant height on marigold was also documented previously by (Rai \& Bordolui, 2020).

Table 1. Variation in plant height $(\mathrm{cm})$ of different China Aster genotypes

\begin{tabular}{|c|c|c|c|c|c|c|c|}
\hline & $\mathbf{G}_{1}$ & $\mathbf{G}_{2}$ & G3 & $\mathbf{G}_{4}$ & G5 & G6 & Mean T \\
\hline \multicolumn{8}{|c|}{ 2018-2019 } \\
\hline $\mathrm{T}_{1}$ & 49.630 & 50.293 & 55.663 & 63.510 & 44.307 & 59.220 & 53.771 \\
\hline $\mathrm{T}_{2}$ & 53.530 & 55.923 & 59.743 & 69.437 & 50.080 & 64.147 & 58.810 \\
\hline $\mathrm{T}_{3}$ & 58.327 & 59.563 & 65.850 & 76.017 & 56.443 & 68.113 & 64.052 \\
\hline Mean G & 53.829 & 55.260 & 60.419 & 69.654 & 50.277 & 63.827 & \\
\hline & $\mathbf{T}$ & $\mathbf{G}$ & TX G & & & & \\
\hline $\operatorname{SEm}( \pm)$ & 0.269 & 0.381 & 0.659 & & & & \\
\hline
\end{tabular}




\begin{tabular}{|c|c|c|c|c|c|c|c|}
\hline LSD (0.05) & 0.777 & 1.099 & 1.924 & & & & \\
\hline \multicolumn{8}{|c|}{ 2019-2020 } \\
\hline $\mathrm{T}_{1}$ & 49.200 & 50.250 & 55.577 & 63.250 & 44.233 & 58.890 & 53.567 \\
\hline $\mathrm{T}_{2}$ & 53.407 & 55.850 & 59.627 & 69.143 & 49.830 & 64.020 & 58.646 \\
\hline $\mathrm{T}_{3}$ & 57.997 & 59.510 & 65.610 & 75.963 & 56.400 & 67.860 & 63.890 \\
\hline \multirow[t]{2}{*}{ Mean G } & 53.534 & 55.203 & 60.271 & 69.452 & 50.154 & 63.590 & \\
\hline & $\mathbf{T}$ & G & TX G & & & & \\
\hline $\operatorname{SEm}( \pm)$ & 0.264 & 0.373 & 0.647 & & & & \\
\hline LSD (0.05) & 0.762 & 1.078 & 1.867 & & & & \\
\hline
\end{tabular}

\section{Days to Flower Bud Initiation}

Among the genotypes over treatments, longest duration to flower bud initiation was noted for $\mathrm{G}_{1}$ i.e. Arka Kamini (88.511days) during the year 2018-19 followed by $\mathrm{G}_{2}$ i.e. Arka Archana (81.487days), while it was minimum for $\mathrm{G}_{5}$ i.e. local white( 71.756 days) preceded by $\mathrm{G}_{4} \mathrm{Local}$ pink (72.433days).Among the treatments over the genotypes, maximum duration to bud initiation was observed for $\mathrm{T}_{1}$ (80.607 days) i.e., in control condition and it was minimum for $\mathrm{T}_{3}$ (75.071days) i.e., $100 \mathrm{ppm} \mathrm{GA}_{3}$.It has been observed that days required for bud initiation was reduced with the application of $\mathrm{GA}_{3}$. The interaction between $\mathrm{GA}_{3}$ treatment and genotype is noted overall significant though the influence of $\mathrm{GA}_{3}$ concentration on individual genotypes was varied non significantly in genotype $\mathrm{G}_{4}$ for both the doses of $\mathrm{GA}_{3}$ treatments and where no significant difference in days to flower bud initiation was observed. Non-significant difference was observed between the genotype $G_{3}$ and $G_{6}$ for the treatment $T_{2}$ and for the treatment $T_{3}$ i.e. 100 ppm $\mathrm{GA}_{3}$ dose; also in case of genotype $\mathrm{G}_{4}$ and $\mathrm{G}_{5}$ non-significant difference was observed in days to flower bud initiation in control as well as in $\mathrm{T}_{2}$.However, maximum days (80.607days) taken to bud initiation was recorded in the control plot i.e. without application of $\mathrm{GA}_{3}$.

The average performance of the genotypes and influence of $\mathrm{GA}_{3}$ concentration in 201920 was almost similar to that observed in 2018-19, except minimum time taken for flower bud initiation was observed in $\mathrm{G}_{4}$ i.e. Local pink (70.557days) preceded by $\mathrm{G}_{5}$ i.e Local white, (71.567days), which may be due to the variation in climatic conditions during experimentation over the years (Table 2). When considering interaction between treatments and genotypes, overall it was significant. But it was varied non-significantly among the genotypes $\mathrm{G}_{5}$ and $\mathrm{G}_{6}$ for both doses of $\mathrm{GA}_{3}$, between $\mathrm{G}_{4}, \mathrm{G}_{5}$ for both the treatments and for control and $\mathrm{G}_{5}, \mathrm{G}_{6}$ for control. In the year 2019-20; still maximum number of days (90.357days) taken to bud in initiation was recorded for without $\mathrm{GA}_{3}$ application and consistent reduction in days to flower bud initiation was noticed for all the genotypes with enhancement in $\mathrm{GA}_{3}$ concentration. Similar type of result in days to flower to bud initiation was also documented previously by (Mahato et al., 2017).

Table 2. Variation in days to flower bud initiation ( $\mathrm{cm}$ ) of different China Aster genotypes

\begin{tabular}{|l|c|c|c|c|c|c|c|}
\hline & G1 & G2 & G3 & G4 & G5 & G6 & Mean T \\
\hline \multicolumn{7}{|c|}{$\mathbf{2 0 1 8 - 2 0 1 9}$} \\
\hline $\mathrm{T}_{1}$ & 90.357 & 85.343 & 81.150 & 74.377 & 75.197 & 77.217 & 80.607 \\
\hline $\mathrm{T}_{2}$ & 88.820 & 81.073 & 75.723 & 71.923 & 72.143 & 75.373 & 77.509 \\
\hline
\end{tabular}




\begin{tabular}{|c|c|c|c|c|c|c|c|}
\hline $\mathrm{T}_{3}$ & 86.357 & 78.043 & 73.433 & 71.000 & 67.927 & 73.667 & 75.071 \\
\hline Mean G & 88.511 & 81.487 & 76.769 & 72.433 & 71.756 & 75.419 & \\
\hline & $\mathbf{T}$ & $\mathbf{G}$ & TX G & & & & \\
\hline $\operatorname{SEm}( \pm)$ & 0.251 & 0.355 & 0.615 & & & & \\
\hline LSD (0.05) & 0.725 & 1.025 & 1.775 & & & & \\
\hline \multicolumn{8}{|c|}{ 2019-2020 } \\
\hline $\mathrm{T}_{1}$ & 90.433 & 84.400 & 81.057 & 74.597 & 75.200 & 76.467 & 80.359 \\
\hline $\mathrm{T}_{2}$ & 88.980 & 81.203 & 76.960 & 70.930 & 71.963 & 75.707 & 77.624 \\
\hline $\mathrm{T}_{3}$ & 86.690 & 78.110 & 74.043 & 66.143 & 67.537 & 74.000 & 74.421 \\
\hline \multirow[t]{2}{*}{ Mean G } & 88.701 & 81.238 & 77.353 & 70.557 & 71.567 & 75.391 & \\
\hline & $\mathbf{T}$ & $\mathbf{G}$ & TX G & & & & \\
\hline $\operatorname{SEm}( \pm)$ & 0.234 & 0.330 & 0.572 & & & & \\
\hline LSD (0.05) & 0.674 & 0.953 & 1.651 & & & & \\
\hline \multicolumn{8}{|c|}{$\begin{array}{l}\text { Note: } \mathbf{T}=\text { Treatment, } \mathbf{T}_{\mathbf{1}}=\text { Control, } \mathbf{T}_{\mathbf{2}}=50 \mathrm{ppm} \mathrm{GA}_{3}, \mathbf{T}_{\mathbf{3}}=100 \mathrm{ppm} \mathrm{GA}_{3}, \mathbf{G}=\text { Genotypes, } \\
\mathbf{G}_{\mathbf{1}}=\text { Arka Kamini, } \mathbf{G}_{\mathbf{2}}=\text { Arka Archana, } \mathbf{G}_{\mathbf{3}}=\text { Arka Adya, } \mathbf{G}_{\mathbf{4}}=\text { Local pink, } \mathbf{G} \mathbf{5}=\text { Local White, } \\
\mathbf{G}_{\mathbf{6}}=\text { Local Mix }\end{array}$} \\
\hline
\end{tabular}

\section{Days to $50 \%$ flowering}

Significant difference was observed among the genotypes over treatments both the years; highest days to $50 \%$ flowering was recorded in $\mathrm{G}_{1}$ i.e. Arka Kamini (108.778days for first year and 108.520days for second year), followed by genotype $\mathrm{G}_{2}$ i.e. Arka Archana (96.808daysfor first year and 96.922 days for second year) and lowest days to $50 \%$ flowering was recorded in genotype $\mathrm{G}_{4}$ i.e Local Pink (87.254daysfor first year and 87.150 days for second year) preceded by $\mathrm{G}_{5}, \mathrm{G}_{6}$ and $\mathrm{G}_{3}$. Among the treatment over genotypes significant difference was observed. Maximum duration of 50\% flowering was recorded in $\mathrm{T}_{0}$ (97.615 days) and it was consistently reduced with the enhancement in $\mathrm{GA}_{3}$ concentration in both the years. In case of interaction between genotypes and foliar application of $\mathrm{GA}_{3}$ non-significant difference was recorded. Though change in magnitudes for this parameter of individual genotypes after foliar application of $\mathrm{GA}_{3}$ was recorded non-significant in both years, $\mathrm{G}_{1}$ took the maximum number of days to $50 \%$ flowering without application of $\mathrm{GA}_{3}$ irrespective of the years of experimentation followed by that of $\mathrm{G}_{2}, \mathrm{G}_{3}$ and $\mathrm{G}_{6}$. Similar type of result in days to $50 \%$ flowering on rice was also documented previously by (Biswas et al., 2020).

Table 3. Variation in days to $50 \%$ flowering of different China Aster genotypes after $\mathrm{GA}_{3}$ application

\begin{tabular}{|c|c|c|c|c|c|c|c|}
\hline & $\mathbf{G}_{1}$ & $\mathbf{G}_{2}$ & G3 & $\mathbf{G}_{4}$ & G5 & G6 & Mean T \\
\hline \multicolumn{8}{|c|}{ 2018-2019 } \\
\hline $\mathrm{T}_{1}$ & 112.187 & 100.067 & 97.267 & 90.173 & 91.967 & 94.030 & 97.615 \\
\hline $\mathrm{T}_{2}$ & 107.947 & 96.323 & 93.187 & 87.323 & 89.037 & 91.483 & 94.217 \\
\hline $\mathrm{T}_{3}$ & 106.200 & 94.033 & 91.133 & 84.267 & 86.933 & 89.000 & 91.928 \\
\hline \multirow[t]{2}{*}{ Mean G } & 108.778 & 96.808 & 93.862 & 87.254 & 89.312 & 91.504 & \\
\hline & $\mathbf{T}$ & $\mathbf{G}$ & TX G & & & & \\
\hline $\operatorname{SEm}( \pm)$ & 0.175 & 0.247 & 0.428 & & & & \\
\hline LSD (0.05) & 0.505 & 0.714 & NS & & & & \\
\hline \multicolumn{8}{|c|}{ 2019-2020 } \\
\hline
\end{tabular}




\begin{tabular}{|c|c|c|c|c|c|c|c|}
\hline $\mathrm{T}_{1}$ & 112.023 & 100.550 & 97.373 & 90.117 & 92.090 & 94.037 & 97.698 \\
\hline $\mathrm{T}_{2}$ & 107.337 & 96.200 & 93.150 & 87.240 & 89.063 & 91.493 & 94.081 \\
\hline $\mathrm{T}_{3}$ & 106.200 & 94.017 & 91.267 & 84.093 & 86.807 & 89.300 & 91.947 \\
\hline Mean G & 108.520 & 96.922 & 93.930 & 87.150 & 89.320 & 91.610 & \\
\hline & $\mathbf{T}$ & $\mathbf{G}$ & TX G & & & & \\
\hline $\operatorname{SEm}( \pm)$ & 0.160 & 0.226 & 0.391 & & & & \\
\hline LSD (0.05) & 0.461 & 0.652 & NS & & & & \\
\hline \multicolumn{8}{|c|}{$\begin{array}{l}\text { Note: } \mathbf{T}=\text { Treatment, } \mathbf{T}_{\mathbf{1}}=\text { Control, } \mathbf{T}_{\mathbf{2}}=50 \mathrm{ppm} \mathrm{GA}_{3}, \mathbf{T}_{\mathbf{3}}=100 \mathrm{ppm} \mathrm{GA}_{3}, \mathbf{G}=\text { Genotypes, } \\
\mathbf{G}_{\mathbf{1}}=\text { Arka Kamini, } \mathbf{G}_{\mathbf{2}}=\text { Arka Archana, } \mathbf{G}_{\mathbf{3}}=\text { Arka Adya, } \mathbf{G}_{\mathbf{4}}=\text { Local pink, } \mathbf{G} \mathbf{5}=\text { Local White, } \\
\mathbf{G}_{\mathbf{6}}=\text { Local Mix }\end{array}$} \\
\hline
\end{tabular}

\section{Flower Diameter (cm)}

Flower diameter is enhanced with increased dose of foliar application of $\mathrm{GA}_{3}$ over control. Average potentiality of individual genotypes with respect to flower diameter of genotypes over treatments was significantly varied among it selves. During first year (2018-2019), genotype $\mathrm{G}_{6}$ i.e. local mix secured largest average flower diameter $(6.552 \mathrm{~cm})$ followed by genotype $\mathrm{G}_{4}$ i.e. Local pink $(6.456 \mathrm{~cm})$ and $\mathrm{G}_{5}$ i.e. Local white $(6.201 \mathrm{~cm})$ respectively. Beside this, smallest average flower diameter was recorded in the genotype $\mathrm{G}_{1}$ i.e. Arka Kamini $(5.459 \mathrm{~cm})$ proceeded by $\mathrm{G}_{2}$ i.e. Arka Archana and $\mathrm{G}_{3}$ i.e. Arka Adya respectively (Table 4).Among the treatment over genotypes significant difference was observed when considered as average. Largest flower diameter $(6.354 \mathrm{~cm})$ was recorded under $\mathrm{T}_{3}$ i.e. $100 \mathrm{ppm} \mathrm{GA} 3$ treatment and it is reduced towards lower dose application and in control respectively. In case of interaction, change in magnitudes for this parameter of individual genotypes after foliar application of $\mathrm{GA}_{3}$ was recorded significant; maximum flower diameter was noted in genotype $\mathrm{G}_{6}$ i.e. Local mix $(6.823 \mathrm{~cm})$. The interaction between treatments and genotypes significantly varied in first year. Highest value was recorded in $\mathrm{T}_{3} \mathrm{G}_{6}$ and lowest in $\mathrm{T}_{3} \mathrm{G}_{6}$.

The average performance of the genotypes and influence of $\mathrm{GA}_{3}$ concentration in 201920 was almost similar to that observed in 2018-19 with slight change in magnitude which may be due to the variation in climatic conditions during experimentation over the years (Table 4). The interaction between treatments and genotypes, was varied significantly overall though nonsignificant difference is recorded between the genotype $\mathrm{G}_{4}$ and $\mathrm{G}_{6}$ in control for the considered parameter. Largest flower diameter was recorded in genotype $\mathrm{G}_{6}(6.867 \mathrm{~cm})$ and smallest flower diameter was recorded in the genotype $\mathrm{G}_{1}(5.492 \mathrm{~cm})$ as like in first year.

Table 4. Variation in flower diameter of different China Aster genotypes after $\mathrm{GA}_{3}$ application

\begin{tabular}{|l|c|c|c|c|c|c|c|}
\hline & G1 & G2 & G3 & G4 & G5 & G6 & Mean T \\
\hline \multicolumn{7}{|c|}{$\mathbf{2 0 1 8 - 2 0 1 9}$} \\
\hline $\mathrm{T}_{1}$ & 5.237 & 5.360 & 5.603 & 6.187 & 5.770 & 6.257 & 5.736 \\
\hline $\mathrm{T}_{2}$ & 5.463 & 5.823 & 5.970 & 6.473 & 6.323 & 6.577 & 6.105 \\
\hline $\mathrm{T}_{3}$ & 5.677 & 6.053 & 6.353 & 6.707 & 6.510 & 6.823 & 6.354 \\
\hline Mean G & 5.459 & 5.746 & 5.976 & 6.456 & 6.201 & 6.552 & \\
\hline & T & G & T X G & & & & \\
\hline
\end{tabular}




\begin{tabular}{|c|c|c|c|c|c|c|c|}
\hline $\operatorname{SEm}( \pm)$ & 0.009 & 0.013 & 0.023 & & & & \\
\hline LSD (0.05) & 0.027 & 0.039 & 0.067 & & & & \\
\hline \multicolumn{8}{|c|}{ 2019-2020 } \\
\hline $\mathrm{T}_{1}$ & 5.247 & 5.373 & 5.617 & 6.213 & 5.823 & 6.277 & 5.758 \\
\hline $\mathrm{T}_{2}$ & 5.480 & 5.857 & 6.027 & 6.490 & 6.407 & 6.603 & 6.144 \\
\hline $\mathrm{T}_{3}$ & 5.750 & 6.103 & 6.410 & 6.787 & 6.600 & 6.867 & 6.419 \\
\hline \multirow[t]{2}{*}{ Mean G } & 5.492 & 5.778 & 6.018 & 6.497 & 6.277 & 6.582 & \\
\hline & $\mathbf{T}$ & G & TX G & & & & \\
\hline $\operatorname{SEm}( \pm)$ & 0.009 & 0.013 & 0.022 & & & & \\
\hline LSD (0.05) & 0.026 & 0.037 & 0.065 & & & & \\
\hline
\end{tabular}

\section{Head Diameter (cm)}

Head size was consistently increased among the various genotypes with increasing the dose of foliar application of $\mathrm{GA}_{3}$ compared to control. Overall significant difference was observed when considering average performance of genotypes over treatments as well as in case of treatment over genotypes. Though non-significant differences was observed among the genotypes $\mathrm{G}_{1}$ and $\mathrm{G}_{2}, \mathrm{G}_{2}$ and $\mathrm{G}_{3}, \mathrm{G}_{3}$ and $\mathrm{G}_{4}, \mathrm{G}_{4}$ and $\mathrm{G}_{5}$ when considering average performance of the mentioned genotype over the treatments during the year 2018-2019. Highest average head diameter was noted in case of genotype $\mathrm{G}_{5}$ i.e. local white $(2.001 \mathrm{~cm})$ followed by genotype $\mathrm{G}_{6}$ i.e. Local Mix $(1.964 \mathrm{~cm}), \mathrm{G}_{4}$ i.e. Local pink $(1.906 \mathrm{~cm})$ respectively. Smallest head diameter is recorded in the genotype $\mathrm{G}_{3}$ i.e. Arka Adya $(1.808 \mathrm{~cm})$ preceded by $\mathrm{G}_{2}$ and $\mathrm{G}_{1}$ (Table 5). When considering treatments over genotypes, the parameter varied significantly. Highest magnitude in head diameter was noted for $T_{3}$ i.e. $100 \mathrm{ppm}$ foliar application of $\mathrm{GA}_{3}$ and lowest is observed in case of control. Overall significant difference is observed in case of interaction between genotypes and treatments; though non-significant difference is observed between genotype $\mathrm{G}_{1}, \mathrm{G}_{2}, \mathrm{G}_{3}, \mathrm{G}_{4}$, $\mathrm{G}_{5}$ and $\mathrm{G}_{6}$ when critically observing the interaction (Table 5). Highest head diameter was recorded for genotype $\mathrm{G}_{1}$ i.e. Arka Kamini $(2.227 \mathrm{~cm})$ when foliar application of $100 \mathrm{ppm} \mathrm{GA}$ was given.

The average performance of the genotypes and influence of GA3 concentration in 201920 was almost similar to that observed in 2018-19. The trend in performance of individual genotypes for head diameter in second year was also similar to that recorded in first year, especially with regard to highest and lowest head size. Interaction between treatments and genotypes, was varied significantly overall though non-significant difference is recorded among the genotype $\mathrm{G}_{1}, \mathrm{G}_{2}, \mathrm{G}_{3}$ and among $\mathrm{G}_{4}, \mathrm{G}_{5}, \mathrm{G}_{6}$ over various treatment. 
Table 5. Variation in head diameter of different China Aster genotypes after $\mathrm{GA}_{3}$ application

\begin{tabular}{|c|c|c|c|c|c|c|c|}
\hline & $\mathbf{G}_{1}$ & $\mathbf{G}_{2}$ & $\mathbf{G}_{3}$ & $\mathbf{G}_{4}$ & G5 & G6 & Mean $\mathbf{T}$ \\
\hline \multicolumn{8}{|c|}{ 2018-2019 } \\
\hline $\mathrm{T}_{1}$ & 1.620 & 1.520 & 1.600 & 1.760 & 1.873 & 1.820 & 1.698 \\
\hline $\mathrm{T}_{2}$ & 1.770 & 1.930 & 1.833 & 1.793 & 2.010 & 2.007 & 1.891 \\
\hline $\mathrm{T}_{3}$ & 2.227 & 2.053 & 1.990 & 2.163 & 2.120 & 2.067 & 2.103 \\
\hline \multirow[t]{2}{*}{ Mean G } & 1.872 & 1.834 & 1.808 & 1.906 & 2.001 & 1.964 & \\
\hline & $\mathbf{T}$ & G & TX G & & & & \\
\hline SEm( \pm ) & $\mathbf{0 . 0 3 0}$ & 0.043 & 0.074 & & & & \\
\hline LSD (0.05) & 0.087 & 0.123 & 0.213 & & & & \\
\hline \multicolumn{8}{|c|}{ 2019-2020 } \\
\hline $\mathrm{T}_{1}$ & 1.640 & 1.550 & 1.613 & 1.807 & 1.887 & 1.843 & 1.753 \\
\hline $\mathrm{T}_{2}$ & 1.797 & 1.920 & 1.853 & 1.823 & 2.050 & 2.103 & 1.924 \\
\hline $\mathrm{T}_{3}$ & 2.257 & 2.080 & 2.017 & 2.177 & 2.153 & 2.107 & 2.132 \\
\hline \multirow[t]{2}{*}{ Mean G } & 1.898 & 1.850 & 1.828 & 1.936 & 2.030 & 2.018 & \\
\hline & $\mathbf{T}$ & $\mathbf{G}$ & TXG & & & & \\
\hline $\operatorname{SEm}( \pm)$ & 0.027 & 0.038 & 0.065 & & & & \\
\hline LSD (0.05) & 0.077 & 0.108 & 0.188 & & & & \\
\hline \multicolumn{8}{|c|}{$\begin{array}{l}\text { Note: } \mathbf{T}=\text { Treatment, } \mathbf{T}_{\mathbf{1}}=\text { Control, } \mathbf{T}_{\mathbf{2}}=50 \mathrm{ppm} \mathrm{GA}_{3}, \mathbf{T}_{\mathbf{3}}=100 \mathrm{ppm} \mathrm{GA}_{3}, \mathbf{G}=\text { Genotypes } \\
\mathbf{G}_{\mathbf{1}}=\text { Arka Kamini, } \mathbf{G}_{\mathbf{2}}=\text { Arka Archana, } \mathbf{G}_{\mathbf{3}}=\text { Arka Adya, } \mathbf{G}_{\mathbf{4}}=\text { Local pink, } \mathbf{G} \mathbf{5}=\text { Local White } \\
\mathbf{G}_{\mathbf{6}}=\text { Local Mix }\end{array}$} \\
\hline
\end{tabular}

\section{Number of Flower Plant ${ }^{-1}$}

Overall significant difference was observed when average was made among the genotypes over treatments for both the years; in the year 2018-2019 highest average number of flower per plant was recorded in $\mathrm{G}_{5}$ i.e. Local White (36.800) followed by genotype $\mathrm{G}_{2} \mathrm{and} \mathrm{G}_{1}$ (Table 6)and lowest average number of flower was recorded in genotype G6i.e Local Mix (24.456) preceded by $\mathrm{G}_{3}$ and $\mathrm{G}_{1}$ (Table 6). Among the treatment over genotypes significant difference was observed. Maximum number of flowers was recorded in $\mathrm{T}_{3}$ (36.844) and it was consistently reduced with the lower $\mathrm{GA}_{3}$ concentration in both the years. In case of interaction, significant difference was observed overall but when observing critically, non- significant difference is observed between the performance of the genotype $\mathrm{G}_{3}$ and $\mathrm{G}_{4}, \mathrm{G}_{1}$ and $\mathrm{G}_{2}$ over control and in case of genotype $\mathrm{G}_{3}$ and $\mathrm{G}_{6}, \mathrm{G}_{1}$ and $\mathrm{G}_{2}, \mathrm{G}_{4}$ and $\mathrm{G}_{1}$ over $T_{2}$ and in between the genotype $\mathrm{G}_{1}$ and $\mathrm{G}_{2}$ over $\mathrm{T}_{3}$. Maximum number of flowers was recorded in $\mathrm{T}_{3}$ (36.844) and it was consistently reduced with the decrease in $\mathrm{GA}_{3}$ concentration in both the years

Similar pattern of improvement in flower number was recognized after utilization of $\mathrm{GA}_{3}$ in second year as like as first year. The performance of individual genotypes for number of flowers per plant in second year was as likewise as that recorded in first year, especially with respect to maximum and minimum number of flower (Table 6). Interaction of genotypes with the treatment was noted overall significant. Though insignificant difference was noticed between the genotype $\mathrm{G}_{3}$ and $\mathrm{G}_{4}$ under unsprayed plot, in addition to this non-significant difference was observed among the genotypes $\mathrm{G}_{1}, \mathrm{G}_{2}, \mathrm{G}_{4}$ and between $\mathrm{G}_{3}$ and $\mathrm{G}_{6}$ for application of 50ppm $\mathrm{GA}_{3}$ when observing critically (Table 6). 
Table 6. Variation in number flower plat ${ }^{-1}$ of different China Aster genotypes after $\mathrm{GA}_{3}$ application

\begin{tabular}{|c|c|c|c|c|c|c|c|}
\hline & $\mathbf{G}_{1}$ & $\mathbf{G}_{2}$ & $\mathbf{G}_{3}$ & $\mathbf{G}_{4}$ & $\mathbf{G}_{5}$ & G6 & Mean T \\
\hline \multicolumn{8}{|c|}{ 2018-2019 } \\
\hline $\mathrm{T}_{1}$ & 22.533 & 24.467 & 20.400 & 20.533 & 28.433 & 17.767 & 22.356 \\
\hline $\mathrm{T}_{2}$ & 29.933 & 30.633 & 24.500 & 28.767 & 34.833 & 25.633 & 29.050 \\
\hline $\mathrm{T}_{3}$ & 37.700 & 38.467 & 32.867 & 34.933 & 47.133 & 29.967 & 36.844 \\
\hline \multirow[t]{2}{*}{ Mean G } & 30.056 & 31.189 & 25.922 & 28.078 & 36.800 & 24.456 & \\
\hline & $\mathbf{T}$ & $\mathbf{G}$ & T X G & & & & \\
\hline $\operatorname{SEm}( \pm)$ & 0.375 & 0.530 & 0.918 & & & & \\
\hline LSD (0.05) & 1.082 & 1.531 & 2.651 & & & & \\
\hline \multicolumn{8}{|c|}{ 2019-2020 } \\
\hline $\mathrm{T}_{1}$ & 22.500 & 25.233 & 20.033 & 20.667 & 28.833 & 16.867 & 22.356 \\
\hline $\mathrm{T}_{2}$ & 29.733 & 30.433 & 23.967 & 29.733 & 34.633 & 25.367 & 28.978 \\
\hline $\mathrm{T}_{3}$ & 37.533 & 38.500 & 33.367 & 35.533 & 46.300 & 29.800 & 36.839 \\
\hline \multirow[t]{2}{*}{ Mean G } & 29.922 & 31.389 & 25.789 & 28.644 & 36.589 & 24.011 & \\
\hline & $\mathbf{T}$ & $\mathbf{G}$ & T X G & & & & \\
\hline $\operatorname{SEm}( \pm)$ & 0.380 & 0.537 & 0.930 & & & & \\
\hline LSD (0.05) & 1.096 & 1.550 & 2.686 & & & & \\
\hline \multicolumn{8}{|c|}{$\begin{array}{l}\text { Note: } \mathbf{T}=\text { Treatment, } \mathbf{T}_{\mathbf{1}}=\text { Control, } \mathbf{T}_{\mathbf{2}}=50 \mathrm{ppm} \mathrm{GA}_{3}, \mathbf{T}_{\mathbf{3}}=100 \mathrm{ppm} \mathrm{GA} 3, \mathbf{G}=\text { Genotypes, } \mathbf{G}_{\mathbf{1}} \\
=\text { Arka Kamini, } \mathbf{G}_{\mathbf{2}}=\text { Arka Archana, } \mathbf{G}_{\mathbf{3}}=\text { Arka Adya, } \mathbf{G}_{\mathbf{4}}=\text { Local pink, } \mathbf{G} \mathbf{5}=\text { Local White, } \mathbf{G}_{\mathbf{6}} \\
=\text { Local Mix }\end{array}$} \\
\hline
\end{tabular}

\section{Number of Seed Flower-1}

Significant difference was observed among the average performance of genotypes over treatments for this trait. Highest number of seeds flower ${ }^{-1}$ was recorded for the genotype $\mathrm{G}_{4}$ (210.751) followed by $\mathrm{G}_{5}$ while smallest number of seeds flower ${ }^{-1}$ was recorded for $\mathrm{G}_{3}$ (100.640) followed by $\mathrm{G}_{1}$ when considering average (Table 7). There was a rise in number of seeds flower ${ }^{-1}$ with enhanced dose of $\mathrm{GA}_{3}$ compared to unsprayed condition. When considering treatments over genotypes, the parameter varied significantly. Highest number of seeds flower ${ }^{-1}$ was recorded for $\mathrm{T}_{3}$ (182.318), and it reduced with decreased dose of $\mathrm{GA}_{3}$ (Table 7).Significant difference was observed in interaction between treatments and genotypes. Highest number of seeds flower ${ }^{-1}$ was recorded for the genotype $\mathrm{G}_{4}$ (218.513) when treated with100ppm $\mathrm{GA}_{3}$ while lowest number of seed per flower head was recorded for the genotype $\mathrm{G}_{3}$ (93.460) in control. It is markable that, potential of producing seeds flower ${ }^{-1}$ was varied genotype to genotype which may conclude that this parameter is genotype specific.

Average performance of genotypes in response to various treatments varied significantly in final year. Highest and lowest number of seeds flower ${ }^{-1}$ was recorded for the same genotypes 
as was in first year. Similar pattern of improvement in flower number was recognized after utilization of $\mathrm{GA}_{3}$ in second year as like as first year. The performance of individual genotypes for number seeds flower ${ }^{-1}$ in second year was as likewise as that recorded in first year with a minor change in magnitude. Significant variation was observed when considering interaction between genotypes and treatments. Highest number of seeds flower ${ }^{-1}$ was recorded in genotype $\mathrm{G}_{4}$ and lowest in case of genotype $\mathrm{G}_{3}$ as likewise in first year with a slight change in magnitude (Table 7).

Table 7. Variation in number of seed flower $^{-1}$ of different China Aster genotypes after $\mathrm{GA}_{3}$ application

\begin{tabular}{|c|c|c|c|c|c|c|c|}
\hline & $\mathbf{G}_{1}$ & $\mathbf{G}_{2}$ & G3 & $\mathbf{G}_{4}$ & G5 & G6 & Mean $T$ \\
\hline \multicolumn{8}{|c|}{ 2018-2019 } \\
\hline $\mathrm{T}_{1}$ & 161.133 & 175.593 & 93.460 & 203.293 & 193.867 & 171.270 & 166.436 \\
\hline $\mathrm{T}_{2}$ & 168.140 & 181.783 & 100.430 & 210.447 & 199.523 & 180.547 & 173.478 \\
\hline $\mathrm{T}_{3}$ & 177.010 & 190.293 & 108.030 & 218.513 & 209.393 & 190.667 & 182.318 \\
\hline \multirow[t]{2}{*}{ Mean G } & 168.761 & 182.557 & 100.640 & 210.751 & 200.928 & 180.828 & \\
\hline & $\mathbf{T}$ & G & T X G & & & & \\
\hline SEm( $( \pm)$ & 0.326 & 0.461 & 0.798 & & & & \\
\hline LSD $(0.05)$ & 0.941 & 1.331 & 2.073 & & & & \\
\hline \multicolumn{8}{|c|}{ 2019-2020 } \\
\hline $\mathrm{T}_{1}$ & 161.300 & 175.377 & 93.370 & 203.223 & 193.887 & 171.330 & 166.415 \\
\hline $\mathrm{T}_{2}$ & 168.483 & 182.243 & 100.223 & 210.113 & 199.857 & 181.470 & 173.732 \\
\hline $\mathrm{T}_{3}$ & 176.993 & 190.477 & 107.533 & 218.060 & 209.143 & 191.013 & 182.203 \\
\hline \multirow[t]{2}{*}{ Mean G } & 168.926 & 182.699 & 100.376 & 210.466 & 200.962 & 181.271 & \\
\hline & $\mathbf{T}$ & G & TX G & & & & \\
\hline $\operatorname{SEm}( \pm)$ & 0.291 & 0.412 & 0.714 & & & & \\
\hline LSD (0.05) & 0.841 & 1.189 & 2.060 & & & & \\
\hline
\end{tabular}

\section{Test Weight (g)}

Unlike other parameters, test weight of seeds of different genotypes was recorded for final year only. Significant difference was observed overall when average was made among the genotypes over treatment. Though non-significant difference was observed between average test weight in between $\mathrm{G}_{4}$ and $\mathrm{G}_{5}$; highest average test weight was recorded in $\mathrm{G}_{1}(1.922)$ followed by $\mathrm{G}_{6}$ and $\mathrm{G}_{3}$ while lowest average test weight was noticed in $\mathrm{G}_{2}$ preceded by $\mathrm{G}_{5}$ and $\mathrm{G}_{4}$.Impact of foliar application of $\mathrm{GA}_{3}$ on various genotypes recorded significant when considering average where highest test weight was recorded for $\mathrm{T}_{3}$ (1.944). When considering interaction of treatments with genotypes, overall significant difference was observed. But when observing critically, some genotypes like $\mathrm{G}_{3}, \mathrm{G}_{4}$ in $\mathrm{T}_{1}$ and $\mathrm{G}_{5} ; \mathrm{G}_{1}$ and $\mathrm{G}_{6}$ in $\mathrm{T}_{1}$ again $\mathrm{G}_{4}, \mathrm{G}_{5}$ and $\mathrm{G}_{6}$ in $\mathrm{T}_{2} ; \mathrm{G}_{1}, \mathrm{G}_{5}$ and $\mathrm{G}_{6}$ in $\mathrm{T}_{2}$ showed insignificant difference in their test weight. 
Table 8. Variation in test weight of seed different China Aster genotypes after $\mathrm{GA}_{3}$ application

\begin{tabular}{|c|c|c|c|c|c|c|c|}
\hline & $\mathbf{G}_{1}$ & $\mathbf{G}_{2}$ & G3 & $\mathbf{G}_{4}$ & G5 & G6 & Mean T \\
\hline $\mathrm{T}_{1}$ & 1.813 & 1.673 & 1.740 & 1.737 & 1.720 & 1.793 & 1.746 \\
\hline $\mathrm{T}_{2}$ & 1.920 & 1.750 & 1.840 & 1.817 & 1.803 & 1.903 & 1.839 \\
\hline $\mathrm{T}_{3}$ & 2.033 & 1.860 & 1.930 & 1.900 & 1.920 & 2.020 & 1.944 \\
\hline \multirow[t]{2}{*}{ Mean G } & 1.922 & 1.761 & 1.837 & 1.818 & 1.814 & 1.906 & \\
\hline & $\mathbf{T}$ & G & $\mathbf{T} \times \mathbf{G}$ & & & & \\
\hline $\operatorname{SEm}( \pm)$ & 0.003 & 0.005 & 0.008 & & & & \\
\hline LSD $(0.05)$ & 0.010 & 0.014 & 0.024 & & & & \\
\hline \multicolumn{8}{|c|}{$\begin{array}{l}\text { Note: } \mathbf{T}=\text { Treatment, } \mathbf{T}_{\mathbf{1}}=\text { Control, } \mathbf{T}_{\mathbf{2}}=50 \mathrm{ppm} \mathrm{GA}_{3}, \mathbf{T}_{\mathbf{3}}=100 \mathrm{ppm} \mathrm{GA}, \mathbf{G}=\text { Genotypes } \\
\mathbf{G}_{\mathbf{1}}=\text { Arka Kamini, } \mathbf{G}_{\mathbf{2}}=\text { Arka Archana, } \mathbf{G} \mathbf{3}=\text { Arka Adya }, \mathbf{G}_{\mathbf{4}}=\text { Local pink, } \mathbf{G} \mathbf{5}=\text { Local White }, \\
\mathbf{G}_{\mathbf{6}}=\text { Local Mix }\end{array}$} \\
\hline
\end{tabular}

\section{Seed Yield Plant ${ }^{-1}(\mathrm{~g})$}

Significant difference was observed among the average performance of genotypes over treatments in $1^{\text {st }}$ years. Highest average seed yield plant ${ }^{-1}$ was recorded for the genotype $G_{5}$ (3.577g) followed by $\mathrm{G}_{4}(3.183 \mathrm{~g})$. Lowest yield plant ${ }^{-1}$ was recorded in $\mathrm{G}_{3}$ for both the years. When considering treatments over genotypes significant variation was noticed with highest magnitude of seed yield plant ${ }^{-1}$ in $\mathrm{T}_{3}$ for both the years; concluding that application of $\mathrm{GA}_{3}$ has a positive impact on seed yield. In case of interaction effect, overall significant variation was observed. Highest seed yield plant ${ }^{-1}$ was recorded in $\mathrm{G}_{5}(3.980 \mathrm{~g})$ when treated with 100ppm GA 3 . On the other hand, lowest seed yield plant ${ }^{-1}$ was recorded in $\mathrm{G}_{3}(1.860 \mathrm{~g})$ in control.

Average performance of genotypes in response to foliar application of $\mathrm{GA}_{3}$ varied significantly in final year. Highest and lowest seed yield plant ${ }^{-1}$ was recorded for the same genotypes as noted in first year. Similar pattern of improvement in seed yield was recognized after utilization of $\mathrm{GA}_{3}$ in second year just like first year. The performance of individual genotypes for seed yield plant ${ }^{-1}$ in second year was as likewise as that recorded in first year with a minor change in magnitude. Significant variation was observed when considering interaction between genotypes and treatments; with highest yield of $3.987 \mathrm{~g}$ in $\mathrm{G}_{3}$ when treated by $\mathrm{T}_{3}$. Similar type of result in seed yield plant ${ }^{-1}$ was also documented previously by (Chakraborty et al., 2019).

Table 9. Variation in seed yield plant $^{-1}$ (g) of different China Aster genotypes after $\mathrm{GA}_{3}$ application

\begin{tabular}{|c|c|c|c|c|c|c|c|}
\hline & $\mathbf{G}_{1}$ & $\mathbf{G}_{2}$ & $\mathbf{G}_{3}$ & $\mathbf{G}_{4}$ & G5 & G6 & Mean T \\
\hline \multicolumn{8}{|c|}{ 2018-2019 } \\
\hline $\mathrm{T}_{1}$ & 2.340 & 2.280 & 1.860 & 2.500 & 2.923 & 2.007 & 2.318 \\
\hline $\mathrm{T}_{2}$ & 3.337 & 3.150 & 2.777 & 3.463 & 3.827 & 3.053 & 3.268 \\
\hline $\mathrm{T}_{3}$ & 3.460 & 3.353 & 3.057 & 3.587 & 3.980 & 3.247 & 3.447 \\
\hline Mean G & 3.044 & 2.928 & 2.564 & 3.183 & 3.577 & 2.769 & \\
\hline & $\mathbf{T}$ & G & TX G & & & & \\
\hline $\operatorname{SEm}( \pm)$ & 0.008 & 0.011 & 0.018 & & & & \\
\hline
\end{tabular}




\begin{tabular}{|c|c|c|c|c|c|c|c|}
\hline LSD (0.05) & 0.022 & 0.031 & 0.053 & & & & \\
\hline \multicolumn{8}{|c|}{ 2019-2020 } \\
\hline $\mathrm{T}_{1}$ & 2.361 & 2.290 & 1.897 & 2.513 & 2.947 & 2.053 & 2.343 \\
\hline $\mathrm{T}_{2}$ & 3.347 & 3.153 & 2.770 & 3.490 & 3.860 & 3.063 & 3.281 \\
\hline $\mathrm{T}_{3}$ & 3.520 & 3.420 & 3.060 & 3.610 & 3.987 & 3.347 & 3.491 \\
\hline \multirow[t]{2}{*}{ Mean G } & 3.076 & 2.954 & 2.576 & 3.204 & 3.598 & 2.821 & \\
\hline & $\mathbf{T}$ & G & TX G & & & & \\
\hline $\operatorname{SEm}( \pm)$ & 0.007 & 0.009 & 0.016 & & & & \\
\hline LSD (0.05) & 0.019 & 0.027 & 0.047 & & & & \\
\hline
\end{tabular}

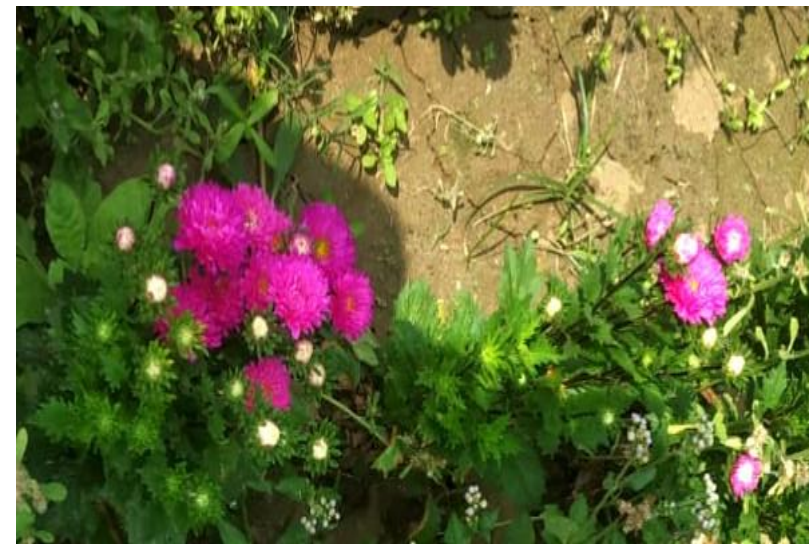

i)Arka $\operatorname{Kamini}\left(V_{1}\right)$

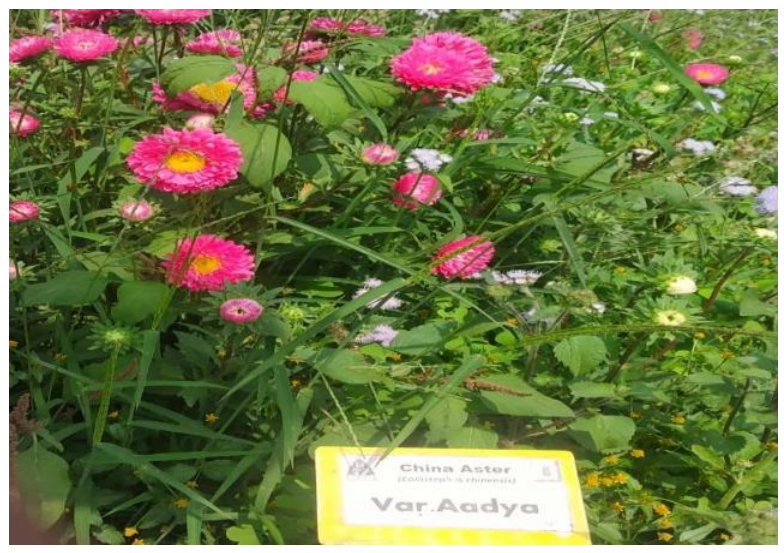

iii)Arka Aadya(V3)

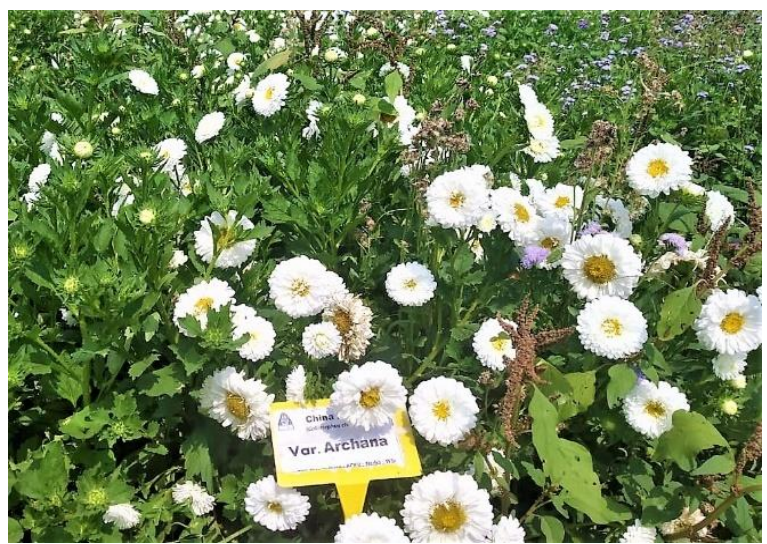

ii)Arka $\operatorname{Archana}\left(V_{2}\right)$

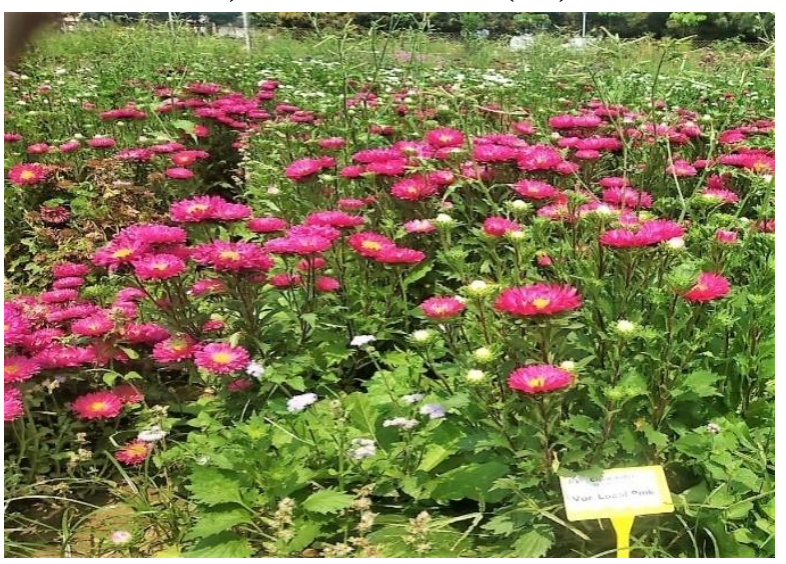

iv)Local Pink $\left(\mathbf{V}_{4}\right)$ 


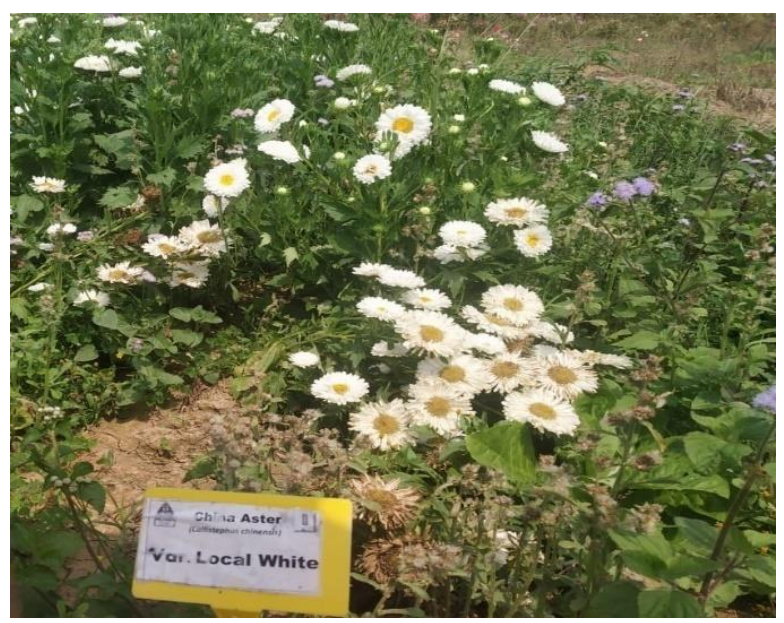

v)Local White( $\left.\mathbf{V}_{5}\right)$

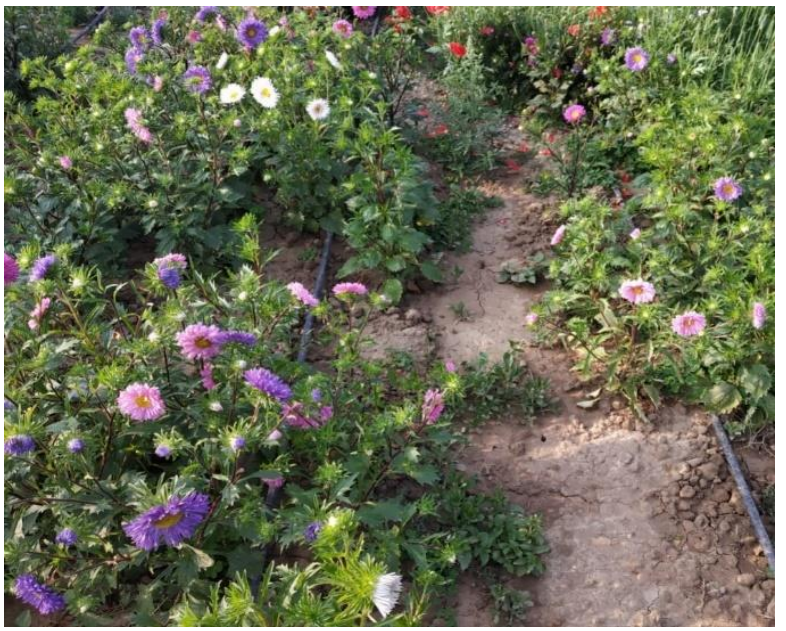

vi)Local Mix( $\left(V_{6}\right)$

Figure 1. Field performance of different genotypes of China aster

\section{CONCLUSIONS}

Among the genotypes, highest flower size was recorded in Local Mix $\left(\mathrm{G}_{6}\right)$. So, it could be recommended as the best performer genotype considering flower diameter. Seed yield plant ${ }^{-1}$ was recorded highest in Local White $\left(\mathrm{G}_{5}\right)$, it could be considered as the best performer genotype considering its higher number of flowers plant ${ }^{-1}$ and number of seeds flower ${ }^{-1} \cdot \mathrm{GA}_{3}(100 \mathrm{ppm})$ could be utilized in a better way for greater enhancement in all those important parameters as overall influence of $\mathrm{GA}_{3}$ has been found to enhance seed yield plant ${ }^{-1}$ and all the important attributes. Seed yield is an important attributes may indicate to recommend foliar application of $100 \mathrm{ppm} \mathrm{GA}_{3}$ for enhancement this trait for all the genotypes. The plant growth and development have been noticed to be positively influenced by GA 3 @ 100 ppm, may lead to recommend foliar application of $100 \mathrm{ppm} \mathrm{GA}_{3}$ for commercial cultivation of this crop irrespective of the genotypes.

\section{REFERENCES}

Anonymous. (2000). Statistical Data on Horticultural crops in Karnataka state, Department of Horticulture, Lalbagh, Bangalore.

Biswas, S., Bordolui, S.K., \& Chattopadhyay, P. (2020). Influence of GA3 on hybrid rice seed production in West Bengal. Journal of Crop and Weed, 16(3), 136-142

Chakraborty, A., Bordolui, S.K., Mahato, M. K., Sadhukhan, R., \& Sri Veda, D.J.M.S.N.K. (2019). Variation in seed production potential of China aster genotypes in the New Alluvial Zone of West Bengal. Journal of Crop and Weed, 15(1), 201-204.

Gavino, R.B., Pi Y \& Abon Jr, C.C. (2008). Application of gibberellic acid $\left(\mathrm{GA}_{3}\right)$ in dosages for three hybrid rice seed production in the Philippines. J. Agril. Technol., 4(1), 183-192. 
Janakiram, T., \& Rao, T. M. (1991). Genetic improvement of marigold. In :Floriculture Technology, Trade and Trends, Eds. Prakash, J. and Bhandary, K. R. Oxford and IBH Co. Pvt. Ltd., New Delhi, pp. 331-335.

Mahato, M. K., Bordolui, S. K., Sadhukhan, R., \& Moharana, R. L. 2017. Evaluation of seed production potential of China Aster in New Alluvial zone, The Bioscan, 12(3), 16491651.

Nagaraju, D., Reddy, B. S., Patil, R. T., Gangadharappa, T. M., \& Kulkarni, B. S. (2004). Effects of dates of planting on flowering and flower quality of China aster (Callistephus chinensis Nees.) cv. Kamini. Journal of Ornamental Horticulture, 7(3-4), 132-134.

Raghava, S. P. S. (1984). Genetical studies in China aster (Callistephus chinensis L.). University of Agricultural Sciences Bangalore, India, PhD Thesis.

Ray, J., \& Bordolui, S.K. (2020). Effect of $\mathrm{GA}_{3}$ on marigold seed production in Gangetic Alluvial Zone. Journal Crop and Weed, 16(1), 120-126.

Yuan, L., Wu, X., Liao, F., Ma, G. and Xu, Q. (2003). Hybrid Rice Technology. China Agricultural Press, Beijing, China, pp. 132.

Yuan, L.P. (1985). A Concise Course in Hybrid Rice. Changsha, China: Human Technology Press.

\section{Copyrights}

Copyright for this article is retained by the author(s), with first publication rights granted to the journal. This is an open-access article distributed under the terms and conditions of the Creative Commons Attribution license (http://creativecommons.org/licenses/by/4.0). 